\title{
CONFECÇÃO DE PONTES DE MACARRÃO COMO APOIO AOS PROCESSOS DE ENSINO E DE APRENDIZAGEM EM ENGENHARIA
}

\author{
Wender Coelho de Oliveira ${ }^{1}$ \\ Júlio César da Silva ${ }^{2}$
}

Resumo: O intuito de calcular e confeccionar as pontes de macarrão, chamadas também de pontes de espaguete, é levar os estudantes de Engenharia Civil a pôr seus conhecimentos em prática, já adquiridos na primeira metade do curso de graduação. Esta finalidade consiste em mostrar aos alunos que estes são capazes de resolver problemas de engenharia com conhecimentos básicos do curso já alcançados, sabendo que grande parte dos alunos não consegue compreender como será utilizado em prática o cálculo, a física, a mecânica dos sólidos, dentre outras disciplinas, como futuros profissionais. As competições de pontes de macarrão entre equipes de estudantes, atualmente, são bastante comuns nas universidades brasileiras e do exterior, na qual a estrutura que suportar a maior carga, antes do colapso, será a melhor da competição. Esta prática proporciona uma maior motivação aos alunos, ao saber que todo este conhecimento absorvido é válido e tem utilidade, recompensando-os também com um belo trabalho prático realizado após todo o processo de execução e ao ver seu projeto sendo testado.

Palavras-chave: Pontes de Macarrão; Estruturas; Trabalho prático; Ftool; Excel.

\footnotetext{
${ }^{1}$ Engenharia Civil/Universidade do Grande Rio (UNIGRANRIO), Brasil. E-mail: wendercoliveira@gmail.com.

2 Engenharia Civil/Universidade do Grande Rio (UNIGRANRIO), Brasil. E-mail: jcesarop@gmail.com.
} 